\title{
Experimental study on the mechanical behavior of RPC filled square steel tube columns subjected to eccentric compression
}

\author{
Wenxiu Hao*, Xiao Xu, Zhiqiang Niu \\ Hebei Agricultural University, Baoding 071001, China \\ *bwxansys@126.com
}

\begin{abstract}
In order to study the mechanical behavior of reactive powder concrete (RPC) filled square steel tubular columns, this paper designs an eccentric compression experiment for 12 specimens of RPC filled square steel tubular columns and studies the effects of failure form, load-displacement curve, slenderness ratio, steel ratio and eccentricity ratio of an eccentrically loaded columns on its mechanical behavior. At the same time, it also compares the experiment results with the bearing capacity calculated with relevant specifications and uses Abaqus to carry out numerical simulation of eccentrically loaded columns. The results show that, the failure form of the eccentrically loaded RPC filled square steel tubular column shows local buckling failure. Before the ultimate load is reached, there is no significant change on the surface of the specimen, and the yield stage of the loaddisplacement curve is not obvious, either. The results of the bearing capacity calculation formula recommended in CECS28-2012 are close to the experiment results and relatively conservative, so it is more applicable to the bearing capacity design of eccentrically loaded RPC filled square steel tubular columns. The results of the numerical simulation analysis are in good agreement with the experimental results, which can provide theoretical support for engineering practice.
\end{abstract}

KEYWORDS. Square steel tube; Reactive powder concrete; Column; Eccentric compression; Mechanical behavior.

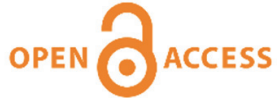

Citation: Hao, W., Xu, X., Niu, Z., N., Experimental study on the mechanical behavior of RPC filled square steel tube columns subjected to eccentric compression, Frattura ed Integrità Strutturale, 46 (2018) 391-399.

Received: 31.07.2018

Accepted: 17.09 .2018

Published: 01.10 .2018

Copyright: (C) 2018 This is an open access article under the terms of the CC-BY 4.0, which permits unrestricted use, distribution, and reproduction in any medium, provided the original author and source are credited.

\section{INTRODUCTION}

$\mathrm{T}$ he concrete filled square steel tubular structure has advantages such as simple structure, convenient connection, high bearing capacity and good seismic performance, making it widely used in industrial premises, high-rise buildings, bridges and other structures. The building space is often limited, but it can be well utilized if the slenderness ratios of the columns are large, which requires the concrete-filled steel tubular columns to have not only high bearing capacity, but also strong lateral stiffness. To achieve these two requirements, we not only have to increase the steel 
ratios and improve the section forms of the columns, but also need to make sure they are filled with high-performance concrete.

Reactive powder concrete (RPC) is a new ultra-high-performance cement-based composite [1] with excellent mechanical properties such as ultra high strength, toughness and durability. Compared with high-strength concrete (HSC), the 200MPalevel RPC has 2-4 times its compressive strength, 3-10 times its flexural strength and 200 times its fracture energy. The RPC filled steel tube can significantly improve the strength and deformation performance of the RPC as the steel tube can constrain its deformation. Compared with ordinary concrete filled steel tubes, the RPC filled ones, have obvious mechanical advantages in reducing the cross-sectional dimensions of components and improving their bearing capacity and lateral stiffness. Therefore, as a new type of composite structure, RPC filled square steel tube has a broad application prospect in civil engineering.

At present, there are few researches on RPC filled square steel tubular columns at home and abroad. By carrying out an eccentric loading experiment on RPC filled square steel tubular columns, this paper attempts to study the mechanical behavior of eccentrically loaded RPC filled square steel tubular columns as well as their influencing factors. At the same time, it compares and analyzes the experimental results and the theoretical values of bearing capacity which were calculated with relevant specifications (or codes), and finds the calculation formula of bearing capacity suitable for RPC filled square steel tubular columns. In addition, this paper utilizes the finite element software Abaqus to carry out numerical simulation of the eccentrically loaded RPC filled square steel tubular columns, which provides a theoretical basis for engineering practice.

\section{OVERVIEW OF THE EXPERIMENT}

\section{Preparing the specimens}

12 PC materials include P.O 42.5 ordinary Portland cement (C), silica fume (SF), quartz sand (QU), Super plasticizers (SU), steel fiber (with a diameter of about $0.18 \sim 0.20 \mathrm{~mm}$ and a length of $12 \sim 14 \mathrm{~mm}$ ) and water $(\mathrm{W})$. By reference to relevant documents [2-3], the mix ratios are shown in Tab. 1, where $\mathrm{B}=\mathrm{C}+\mathrm{SF}$, the proportion of steel fiber is volume ratio, and the others are mass ratios. The mechanical properties of RPC are shown in Tab. 2.

\begin{tabular}{cccccc}
\hline Cement & Silica fume & Quartz sand & Super-plasticizers & Water-binder ratio & Steel fiber \\
C & SF/C & QU/C & SU/B & W/B & Vs $/ \mathrm{V}$ \\
1 & 0.21 & 1.8 & 0.035 & 0.23 & $1 \%$ \\
\hline
\end{tabular}

Table 1: Mix Ratios of RPC.

\begin{tabular}{cccc}
\hline Strength type & $\begin{array}{c}\text { Cube compressive strength } \\
\mathrm{f}_{\mathrm{cu}} / \mathrm{N} / \mathrm{mm}^{2}\end{array}$ & $\begin{array}{c}\text { Axial compressive strength } \\
\mathrm{f}_{\mathrm{c}} / \mathrm{N} / \mathrm{mm}^{2}\end{array}$ & $\begin{array}{c}\text { Splitting tensile strength } \\
\mathrm{f}_{\mathrm{ct}} / \mathrm{N} / \mathrm{mm}^{2}\end{array}$ \\
Value & 93.49 & 69.0 & 11.43 \\
\hline
\end{tabular}

Table 2: Mechanical properties of RPC.

The steel tubes are all straight-seam square steel tubes. The cross-section dimensions of all specimens are all $100 \mathrm{~mm} \times 100 \mathrm{~mm}$. According to GB/T 228.1-2010 and GB/T 228-2002 Metallic Materials-Tensile Experimenting at Ambient Temperature, the mechanical properties of these specimens were experimented, as shown in Tab. 3.

\begin{tabular}{ccccc}
\hline $\begin{array}{c}\text { Nominal wall } \\
\text { thickness }\end{array}$ & $\begin{array}{c}\text { Measured wall } \\
\text { thickness } \\
\mathrm{t} / \mathrm{mm}\end{array}$ & $\begin{array}{c}\text { Yield strength } \\
\mathrm{f}_{\mathrm{y}} / \mathrm{N} / \mathrm{mm}^{2}\end{array}$ & $\begin{array}{c}\text { Tensile strength } \\
\mathrm{f}_{\mathrm{st}} / \mathrm{N} / \mathrm{mm}^{2}\end{array}$ & $\begin{array}{c}\text { Modulus of } \\
\text { elasticity } \\
\mathrm{E}_{\mathrm{s}} / \mathrm{N} / \mathrm{mm}^{2}\end{array}$ \\
3 & 2.63 & 390.3 & 429.9 & $2.17 \times 105$ \\
4 & 3.70 & 383.7 & 423.6 & $2.20 \times 105$ \\
5 & 4.71 & 354.9 & 396.6 & $2.44 \times 105$ \\
\hline
\end{tabular}

Table 3: Mechanical properties of steel tube.

By reference to relevant documents [4-7], 12 RPC filled square steel tubular column specimens were designed in this experiment, whose detailed parameters are shown in Tab. 4. Pressure-bearing cover plates were welded at both ends of the 
specimens (a round hole was reserved in the cover plate at one end for pouring of RPC), and the prepared RPC was poured into the steel tubes, the experiment was carried out after natural curing for 28 days. Fig. 1 is the specimen of square steel tube.

\begin{tabular}{ccccccc}
\hline $\begin{array}{c}\text { Specimen } \\
\text { No. }\end{array}$ & $\begin{array}{c}\text { Steel tube wall } \\
\text { thickness } \\
\mathrm{t} / \mathrm{mm}\end{array}$ & $\begin{array}{c}\text { Eccentricity } \\
\mathrm{e} / \mathrm{mm}\end{array}$ & $\begin{array}{c}\text { Length of } \\
\text { specimen } \\
\mathrm{L} / \mathrm{mm}\end{array}$ & $\begin{array}{c}\text { Slenderness } \\
\text { ratio } \\
\lambda\end{array}$ & $\begin{array}{c}\text { Steel ratio } \\
\alpha\end{array}$ & $\begin{array}{c}\text { Confinement } \\
\text { coefficient } \\
\xi\end{array}$ \\
1 & 3 & 20 & 300 & 10.39 & 0.11 & 0.65 \\
2 & 3 & 20 & 600 & 20.78 & 0.11 & 0.65 \\
3 & 3 & 20 & 800 & 27.71 & 0.11 & 0.65 \\
4 & 3 & 20 & 1000 & 34.64 & 0.11 & 0.65 \\
5 & 4 & 20 & 1000 & 34.64 & 0.17 & 0.92 \\
6 & 5 & 20 & 1000 & 34.64 & 0.22 & 1.13 \\
7 & 3 & 40 & 300 & 10.39 & 0.11 & 0.65 \\
8 & 3 & 40 & 600 & 20.78 & 0.11 & 0.65 \\
9 & 3 & 40 & 800 & 27.71 & 0.11 & 0.65 \\
10 & 3 & 40 & 1000 & 34.64 & 0.11 & 0.65 \\
11 & 4 & 40 & 1000 & 34.64 & 0.17 & 0.92 \\
12 & 5 & 40 & 1000 & 34.64 & 0.22 & 1.13 \\
\hline
\end{tabular}

Table 4: Parameters of the Specimens.

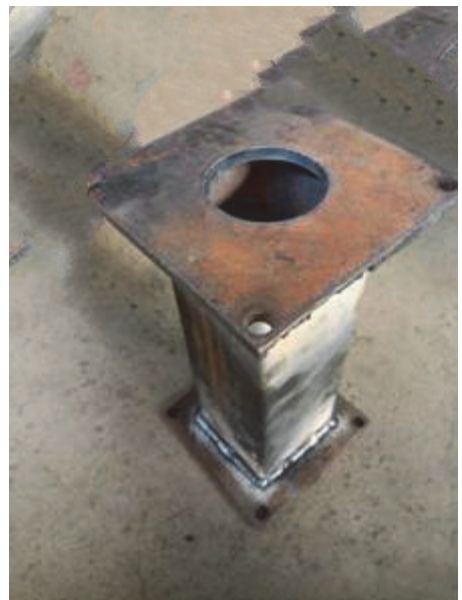

Figure 1: Specimen of the square steel tube.

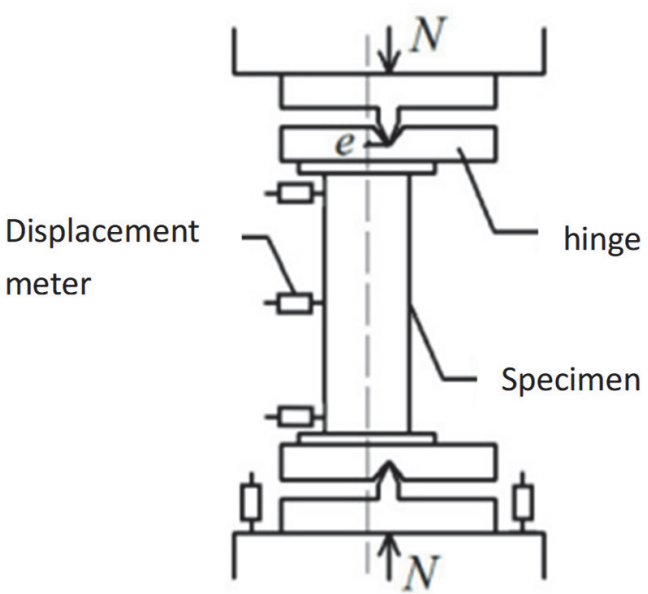

Figure 2: Experimental set.

\section{Experimental equipment}

The experiment was carried out using a 500t hydraulic servo pressure- testing -machine to load pressure, a DH3818 static strain meter to collect experiment data, an electronic displacement meter to measure the lateral displacements of the specimens, and electronic strain gages pasted in the longitudinal and lateral positions at the mid-span of the specimens to measure the strains of the specimens. The experimental set is shown in Fig. 2.

\section{EXPERIMENTAL RESULTS}

\section{Failure forms of the specimens}

7 hrough experimental observations, it was found that the appearances of the RPC filled square steel tubular specimens did not change much until the ultimate load was reached. As the deformation of column gradually increased, the bearing capacity gradually decreased. When the bearing capacity of the column dropped to $95 \%-85 \%$ of the ultimate bearing capacity, the square steel tube showed obvious bending, and the lateral displacement in the mid-span 
was also getting larger. Before the specimen failed, usually it was the pressure side that showed bending first and the final failure form was the local bending deformation of the steel tube. The failure forms of the specimens are shown in Fig. 3.

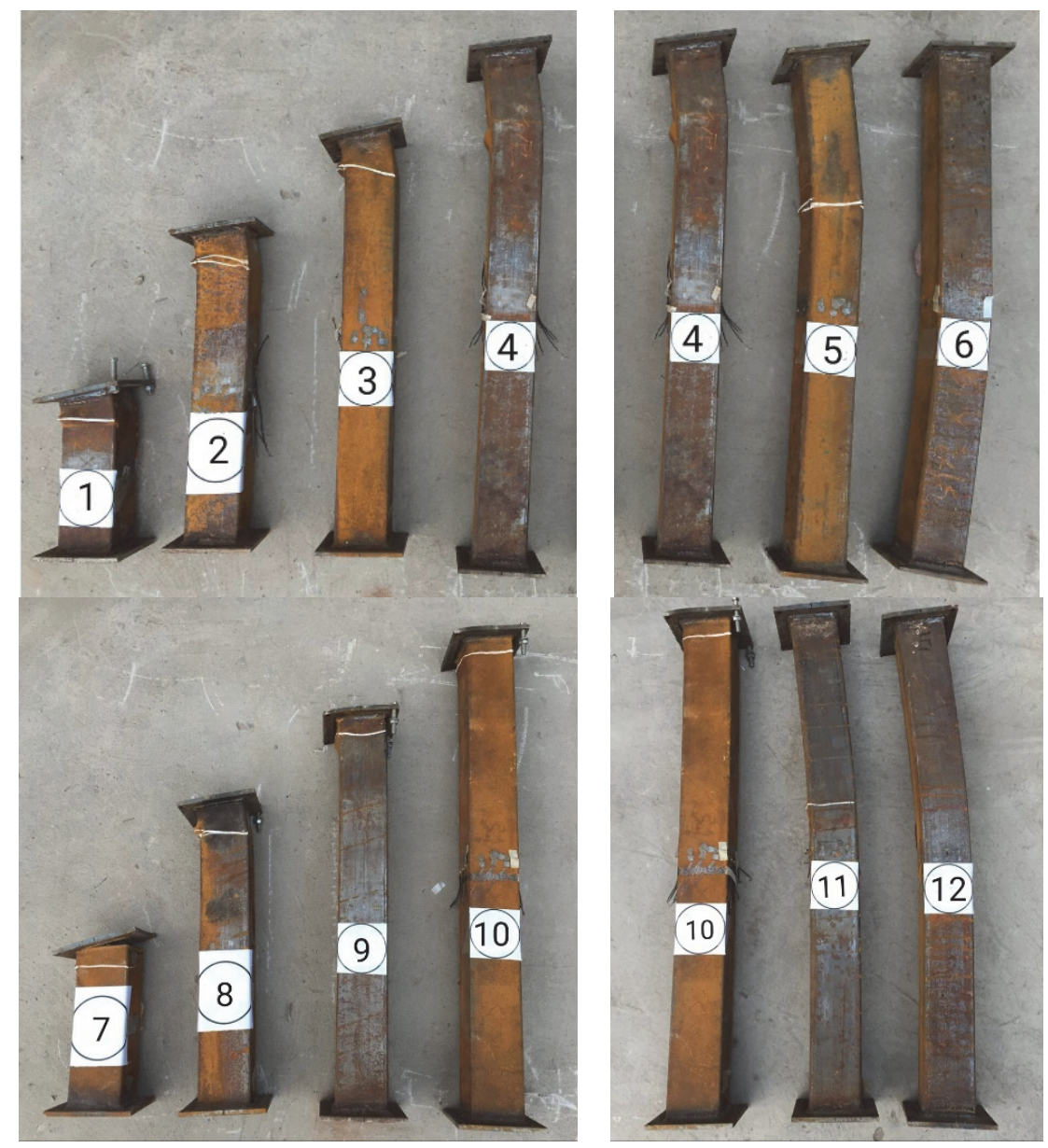

Figure 3: Failure forms of specimens.

When the slenderness ratios and eccentricities of the specimens were the same, if the steel ratios were different, the bent parts would also be different. For example, when the steel ratio $\alpha=0.11$, the bent part of the RPC filled square steel tubular column was about $1 / 10$ of the length from the top of the column; and when the steel ratio $\alpha=0.22$, the bent part of the specimen was almost close to the mid-span of the specimen. This was because when the eccentrically loaded column was being compressed, the bending was extended from its two ends to the middle. The larger the steel ratio, the stronger the deformation resistance of the specimen is.

\section{Load-displacement curves of specimens}

Fig. 4 shows the load-span lateral displacement curves of the specimens. It can be seen that the load-displacement curves of the RPC filled square steel tubular specimens can be roughly divided into three stages: the linear elastic stage, the elasticplastic stage and the descending stage. In the linear elastic stage, the load-displacement curve of the column is basically linear. The descending section of the curve is relatively flat, which shows that the specimen had good ductility and ability to maintain load in the later stage. As the slenderness ratio and eccentricity of the specimen increased, the ultimate bearing capacity of the column was gradually decreased, and the lateral displacement was increased gradually. When the eccentricity $\mathrm{e}=40 \mathrm{~mm}$, for a RPC filled square steel tubular column with a slenderness ratio of $\lambda=10.39,20.78,27.71$ and 34.64, the ultimate bearing capacity was $480 \mathrm{kN}, 450 \mathrm{kN}, 410 \mathrm{kN}$ and $382 \mathrm{kN}$, respectively. When the eccentricity e $=20 \mathrm{~mm}$, for a RPC filled square steel tubular column with a slenderness ratio of $\lambda=10.39,20.78,27.71$ and 34.64 , the ultimate bearing capacity was $708 \mathrm{kN}, 694 \mathrm{kN}, 573 \mathrm{kN}$ and $588 \mathrm{kN}$, respectively. The steel ratio and the confinement coefficient also had great effects on the ultimate bearing capacity and mid-span lateral displacement of the specimen. When the confinement coefficient $\xi=0.65,0.92$ and 1.13 , under the load with an eccentricity of $\mathrm{e}=40 \mathrm{~mm}$, the bearing capacity of the specimen was $382 \mathrm{kN}$, 
$464 \mathrm{kN}$ and $510 \mathrm{kN}$, respectively. In the descending stage of load-displacement curve, for a specimen with a large confinement coefficient, the rate of load drop was small. For example, the descending speed of the curve of a specimen with a confinement coefficient of $\xi=1.13$ was smaller than that with a confinement coefficient of $\xi=0.65$. In summary, the RPC square steel tubular specimens exhibited good ductility, and had greater bearing capacities than ordinary concrete-filled ones.
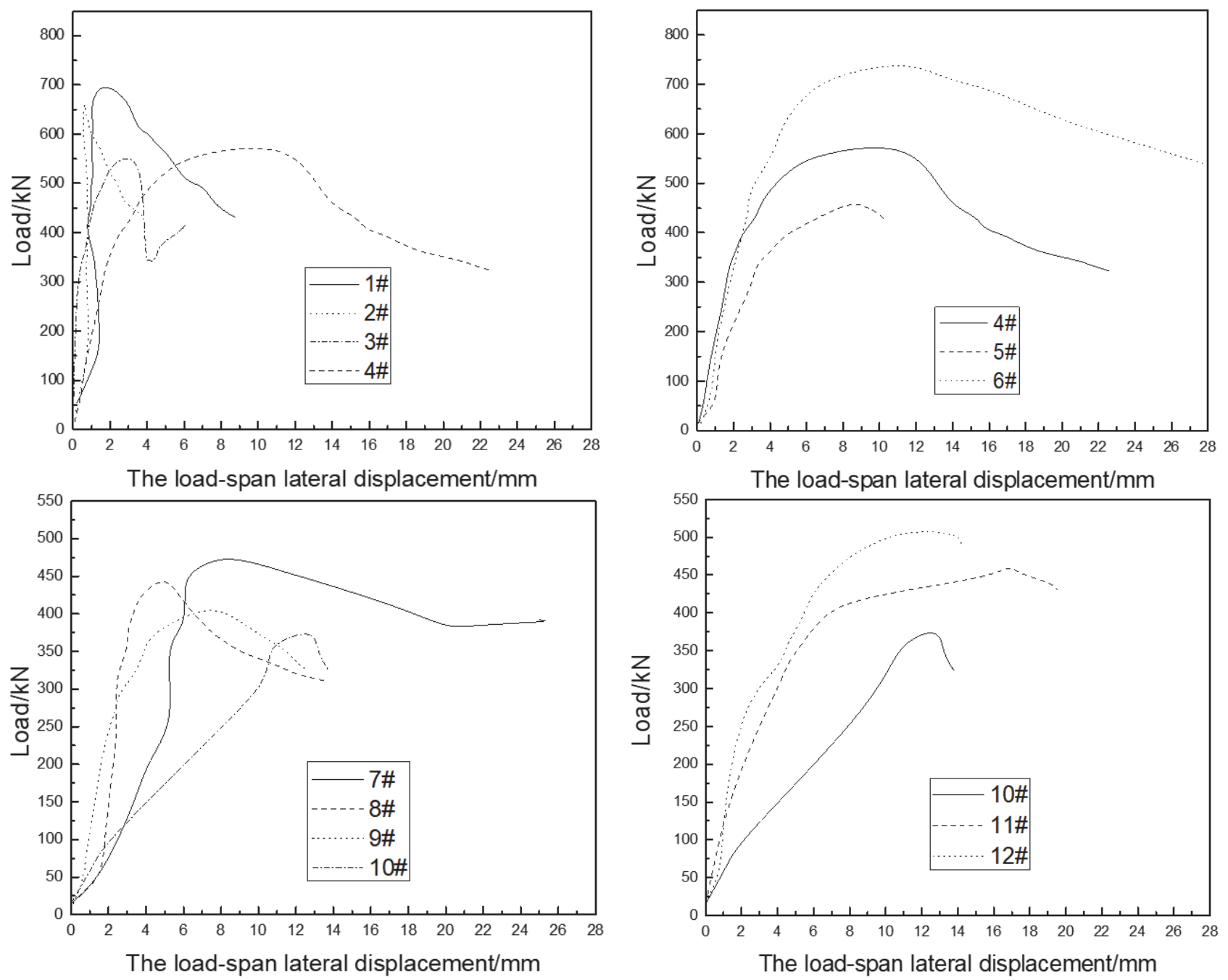

Figure 4: Load-span lateral displacement curves of the specimens.

\section{Comparison of bearing capacity}

Comparison with experimental results in [4] refs that were ordinary concrete-filled square steel tubular column were shown in Tab. 5, their steel ratio is relatively close. When the eccentricity is 20 and 40 , the bearing capacity of the specimen is increased by $172 \mathrm{kN}$ and $142 \mathrm{kN}$ respectively, increasing by $43 \%$ and $53 \%$ respectively. This shows that RPC filled square steel tubular column has obvious advantages.

\begin{tabular}{ccccccc}
\hline $\begin{array}{c}\text { Specimen } \\
\text { No. }\end{array}$ & $\begin{array}{c}\text { Steel tube wall } \\
\text { thickness } \\
\mathrm{t} / \mathrm{mm}\end{array}$ & $\begin{array}{c}\text { Eccentricity } \\
\mathrm{e} / \mathrm{mm}\end{array}$ & $\begin{array}{c}\text { Length of } \\
\text { specimen } \\
\mathrm{L} / \mathrm{mm}\end{array}$ & $\begin{array}{c}\text { Slenderness } \\
\text { ratio } \\
\lambda\end{array}$ & $\begin{array}{c}\text { Steel ratio } \\
\alpha\end{array}$ & $\begin{array}{c}\text { Bearing } \\
\text { capacity }\end{array}$ \\
3 & 2.63 & 20 & 800 & 27.71 & 0.11 & 573.0 \\
{$[4]$ refs } & 2.72 & 20 & 800 & 27.70 & 0.12 & 401.0 \\
9 & 2.63 & 40 & 800 & 27.71 & 0.11 & 410.0 \\
{$[4]$ refs } & 2.72 & 40 & 800 & 27.71 & 0.12 & 268.0 \\
\hline
\end{tabular}

Table 5: Comparison with experimental results in [4] refs. 
The bearing capacity of RPC filled square steel tubular column is an important indicator of engineering design, so an appropriate calculation formula for bearing capacity is very essential. According to the calculation formulas recommended in five commonly used bearing capacity calculation specifications (or codes) for ordinary concrete-filled steel tubes, namely AISC2005 [8], DBJ13-51-2003 [9], GJB4142-2000 [10], CECS28-2012 [11] and GB50936-2014 [12], this paper calculates the eccentric compression capacities of the RPC filled square steel tubular specimens, with the results shown in Tab. 6. It can be seen that, the ratio of bearing capacity $\mathrm{Nu} / \mathrm{N}$ between the experiment result and CECS28-2012 calculated results have a standard deviation of 0.069 , a coefficient of variation of 0.066 , and a mean value of 1.043 . Compared with the others specifications (or codes), the CECS28-2012 calculated results are quite close to the experiment results and also relatively conservative. Therefore, the formula provided in CECS28-2012 is recommended for calculation of the bearing capacity of RPC filled square steel tubular column in engineering practice.

\begin{tabular}{cccccccccccc}
\hline Specimen & Experiment & \multicolumn{2}{c}{ AISC2005 } & \multicolumn{3}{c}{ DBJ13-51-2003 } & \multicolumn{2}{c}{ GJB4142-2000 } & \multicolumn{2}{c}{ CECS28-2012 } & \multicolumn{2}{c}{ GB50936-2014 } \\
No. & $\mathrm{Nu} / \mathrm{kN}$ & $\mathrm{N} / \mathrm{kN}$ & $\mathrm{Nu} / \mathrm{N}$ & $\mathrm{N} / \mathrm{kN}$ & $\mathrm{Nu} / \mathrm{N}$ & $\mathrm{N} / \mathrm{kN}$ & $\mathrm{Nu} / \mathrm{N}$ & $\mathrm{N} / \mathrm{kN}$ & $\mathrm{Nu} / \mathrm{N}$ & $\mathrm{N} / \mathrm{kN}$ & $\mathrm{Nu} / \mathrm{N}$ \\
1 & 708 & 357 & 1.983 & 727 & 0.974 & 902 & 0.785 & 717 & 0.987 & 700 & 1.011 \\
2 & 694 & 353 & 1.964 & 648 & 1.071 & 739 & 0.940 & 642 & 1.081 & 685 & 1.014 \\
3 & 573 & 350 & 1.638 & 602 & 0.952 & 661 & 0.866 & 590 & 0.971 & 673 & 0.852 \\
4 & 588 & 345 & 1.704 & 564 & 1.043 & 600 & 0.980 & 551 & 1.068 & 660 & 0.891 \\
5 & 629 & 424 & 1.482 & 663 & 0.949 & 666 & 0.944 & 614 & 1.025 & 743 & 0.846 \\
6 & 749 & 468 & 1.599 & 736 & 1.018 & 700 & 1.070 & 642 & 1.167 & 802 & 0.934 \\
7 & 480 & 241 & 1.994 & 529 & 0.907 & 734 & 0.654 & 498 & 0.963 & 505 & 0.950 \\
8 & 450 & 239 & 1.882 & 464 & 0.970 & 572 & 0.787 & 446 & 1.009 & 497 & 0.906 \\
9 & 410 & 237 & 1.727 & 430 & 0.954 & 502 & 0.817 & 410 & 0.999 & 490 & 0.837 \\
10 & 382 & 235 & 1.624 & 401 & 0.952 & 450 & 0.849 & 383 & 0.998 & 482 & 0.792 \\
11 & 464 & 298 & 1.557 & 477 & 0.972 & 502 & 0.924 & 425 & 1.092 & 555 & 0.836 \\
12 & 510 & 333 & 1.531 & 533 & 0.956 & 530 & 0.963 & 443 & 1.152 & 608 & 0.839 \\
Mean value & $/$ & $/$ & 1.724 & $/$ & 0.976 & $/$ & 0.881 & $/$ & 1.043 & $/$ & 0.892 \\
Standard & $/$ & $/$ & 0.186 & $/$ & 0.046 & $/$ & 0.111 & $/$ & 0.069 & $/$ & 0.072 \\
deviation & & & & & & & & & & & \\
Coefficient & $/$ & $/$ & 0.108 & $/$ & 0.047 & $/$ & 0.126 & $/$ & 0.066 & $/$ & 0.081 \\
of variation & & & & & & & & & & &
\end{tabular}

Table 6: Bearing capacity of the specimens.

\section{FINITE ELEMENT ANALYSIS}

\section{Finite element model of columns}

his paper simulates the eccentrically loaded RPC filled square steel tubular column using the finite element software Abaqus. The RPC filled square steel tubular column model consists of three parts, namely RPC, an outer steel tube and a loading cover. Both the RPC and the loading cover are modelled with C3D8R brick elements (8-node 3D brick elements with reduced integration); and the steel tube is modelled with S4R shell element (4-node shell elements with reduced integration). The RPC stress-strain relationship [13] is as follows:

The compressive stress-strain relationship of RPC is shown in formula (1):

$$
\begin{aligned}
& y= \begin{cases}1.3 x-0.4 \mathrm{x}^{4}-0.1 \mathrm{x}^{5} & 0 \leq x \leq 1 \\
\frac{x}{6(x-1)^{2}+x} & 1 \leq x\end{cases} \\
& x=\frac{\varepsilon_{i}}{\varepsilon_{c p}} \quad y=\frac{\sigma}{f_{c}}
\end{aligned}
$$

where: $\varepsilon_{c p}$ is the compressive strain when RPC reaches the peak compressive strength, which is set to be $4400 \times 10^{-6}$; $f_{c}$ is the peak compressive strength of RPC, which is set to be $93.49 \mathrm{~N} / \mathrm{mm}^{2}$. 
Considering the crack resistance of steel fiber in RPC, the tensile stress-strain relationship of RPC is shown in formula (2):

$$
\begin{aligned}
& y= \begin{cases}1.1 x+0.8 x^{2}-0.9 x^{3} & 0 \leq x \leq 1 \\
\frac{x}{2(x-1)^{1.7}+x} & x \geq 1\end{cases} \\
& x=\frac{\varepsilon_{i}}{\varepsilon_{\text {ctp }}} \quad y=\frac{\sigma}{f_{c t}}
\end{aligned}
$$

where: $\varepsilon_{c t p}$ is the compressive strain when RPC reaches the peak tensile strength, which is set to be $400 \times 10^{-6}$; $f_{c t}$ is the peak tensile strength of RPC, which is set to be $11.43 \mathrm{~N} / \mathrm{mm}^{2}$.

The stress-strain curve of steel [14] is divided into five stages: elastic, elastic-plastic, plastic, hardening and one-time plastic flow.
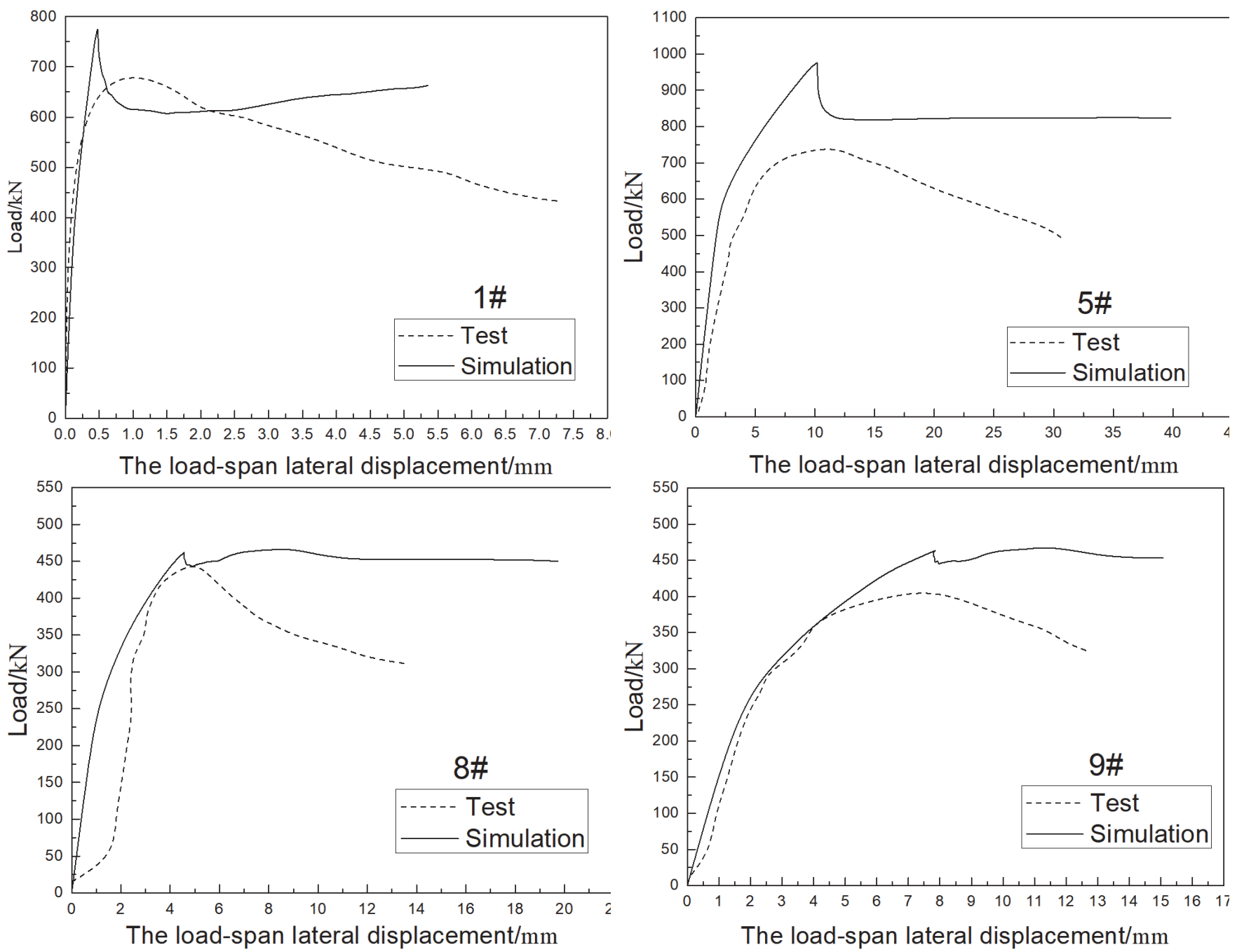

Figure 5: Comparison of the experiment results and analysis results.

\section{Comparison between the experiment results and the analysis results}

Through the finite element simulation analysis of the RPC filled square steel tubular columns, the analysis results of the load-span lateral displacements of some specimens are compared with the experiment results, as shown in Fig. 5 . It can be seen that the experiment results are close to the simulation analysis results, indicating that the model is correct and reasonable and can provide theoretical reference for engineering practice. 


\section{CONCLUSIONS}

(1) Through experimental observations, it was found that the appearances of the eccentrically loaded RPC filled square steel tubular columns did not change much until the ultimate load was reached. The final failure was caused by the local bending of the steel tube. The bent part gradually shifted from the two ends to the mid section of the specimen.

(2) The load-displacement curve of an eccentrically loaded RPC filled square steel tubular column can be roughly divided into three stages: the linear elastic stage, the elastic-plastic stage and the descending stage. The descending section of the curve is relatively flat, which shows that the specimen had good ductility. As the increase of specimen slenderness ratio and eccentricity, the bearing capacity of specimens is gradually decreased, the increase of steel ratio and the confinement coefficient obviously improves the bearing capacity of specimens.

(3) According to theoretical analysis, it is found that the results of bearing capacity test and CECS28-2012 calculation show that the average value of $\mathrm{Nu} / \mathrm{N}$ is 1.043 . Compared with other specifications (or codes), the calculated results are close to the test results and are conservative. Therefore, the formula provided in CECS28-2012 is recommended for calculation of the bearing capacity of RPC filled square steel tubular column in engineering practice.

(4) The simulation analysis results of Abaqus are close to the experiment results, indicating that this finite element model is correct and reasonable and can provide theoretical reference for engineering practice.

\section{ACKNOWLEDGMENTS}

1 he research work was supported by Science and Technology Research Project of Colleges and Universities in Hebei Province (No. ZD2018209) and Key Research and Development Project of Hebei Province (No. 18227209D).

\section{REFERENCES}

[1] Richard, P. and Cheyrezy, M. (1995). Composition of powder concretes, Cement and Concrete Research, 25(7), pp. 1501-1511.

[2] Hao, W.X. and Xu, X. (2012). Experimental study on the mechanical properties of reactive powder concrete with steel fibre, Architecture Technology, 43(1), pp. 35-37.

[3] Hao, W.X. and Xu, X. (2010). Experimental study on the flexural behavior of reactive powder concrete with steel fibre, Concrete, (10), pp. 53-55.

[4] Hu, N.D., Du, X.K., Liu, P. and Niu, Z. (2016). Experimental study on mechanical behavior of recycled aggregate concrete-filled square steel tubular long columns under eccentric compression loading, Journal of Building Structures, (S2), pp. 36-42.

[5] Chen, X.X. (2014). Experimental study on mechanical behavior of recycled aggregate concrete-filled square steel tubular short columns, Baoding: College of Urban and Rural Construction, Agricultural University of Hebei.

[6] Lin, Z.Y., Wu, Y.H. and Shen, Z.Y. (2005). Research on behavior of RPC filled circular steel tube column subjected to axial compression, Journal of Building Structures, 26(4), pp. 52-57.

[7] Song, J. and Chen, F.Y. (2015). Calculation model for thermo-mechanical coupling and 3D numerical simulation for concrete tower of cable-stayed bridge, Mathematical Modelling of Engineering Problems, 2(1), pp. 9-12.

[8] American Institute of Steel Construction. (2005). AISC(2005) Seismic provisions for structural steel buildings, Chicago, IL.

[9] China Association for standardization of engineering construction. (2012). CECS 28-2012 Technical specification for concrete-filled steel tubular structures, Beijing: China planning press.

[10] China Association for standardization of engineering construction. (2013). DBJ13-51-2003 Technical specification for concrete-filled steel tubular structures, Beijing: China architecture and building Press.

[11] Chinese national military standard. (2000). GJB4142-2000 Technical specifications for early-strength model composite structure used for navy port emergency repair in wartime. Beijing: The general logistics department of PLA.

[12] China Association for standardization of engineering construction. (2013). GB50936-2014 Technical code for concrete filled steel tubular structures, Beijing: China architecture and building press. 
[13] Yan, Z.G., Ji, W.Y. and An, M.Z. (2009). Experimental Study and Full-Range Analysis of Reactive Powder Concrete TBeams, Journal of Beijing Jiaotong University, 33(1), pp. 86-90.

[14] Zhong, S.T. (2003). Concrete-filled steel tube structure, Beijing: Tsinghua university press. 